"Енергетика і автоматика", №2, 2021 р.

УДК 621.03

DOI 10.31548/energiya2021.02.081

ЕНЕРГОЕФЕКТИВНА ВОДОНАСОСНА УСТАНОВКА НА ОСНОВІ

ЧАСТОТНО-РЕГУЛЬОВАНОГО ЕЛЕКТРОПРИВОДА

П. Б. Клендій, кандидат технічних наук, доцент

Л. С. Колодійчук, кандидат педагогічних наук, доцент

ВП НУБіП Украйни «Бережанський агротехнічний інститут»

О.П. Дудар, інженер

ВСП «Бережанський фаховий коледж НУБіП Украӥни»

E-mail:pklen_@i.ua

Анотація. Електроводонасосні установки характеризуються не оптимальними режимами роботи та нині є енергозатратними технологіями. Водоспоживання визначається нерівномірністю $i$ формується під впливом багатьох, часто некерованих факторів. Невідповідність запланованого режиму водопостачання реальному водоспожсиванню призводить до виникнення надлишкових напорів, щз зумовлює не лише прямі перевитрати електричної енергії на насосних станиіях, але й підвищує імовірність аварій у мережі, сприяє більшим втратам води за рахунок теч у водопровідній мережі, а отже й додатковим перевитратам електричної енергї̈, яка споживається насосними агрегатами на компенсачію втрати тиску.

При правильному виборі електронасосного агрегату його механічна характеристика $i$ потужність електродвигуна розраховані на забезпечення необхідного тиску в системі при максимальному спожсиванні води (ранкові і вечірні години). В інший час доби із-за зниження споживання води тиск в системі зростає $i$ потрібно прикривати дросельну засувку, а це вимагає постійного чергування біля неї і супроводжусться втратами електроенергії.

В електронасосах, які обладнують нерегульованим електроприводом, регулювання подачі здійснюється практично єдиним традииійним способом дроселюванням на стороні нагнітання. У роботі розкрито необхідність переходу від систем дросельного регулювання насосних агрегатів до систем автоматичного керування иляхом автоматичної підтримки необхідного технологічного параметра, зокрема, тиску при витраті води, що змінюється, за рахунок застосування частотно-регульованих асинхронних електроприводів.

Ключові слова: водонасосна установка, енергозатратні технологї, дроселювання, частотно-регульований електропривод

Актуальність. Системи водопостачання характеризуються далеко не оптимальним режимом роботи і є енергозатратними технологіями. Для оптимізації 
"Енергетика і автоматика", №2, 2021 р.

режиму електроспоживання системи подачі та розподілу води необхідно, в першу чергу, забезпечити раціональну роботу насосних агрегатів та гідравлічних режимів мережі.

Невідповідність запланованого режиму водопостачання реальному водоспоживанню призводить до виникнення надлишкових напорів, що зумовлює не лише прямі перевитрати електричної енергії на насосних станціях, але й підвищує імовірність аварій в мережі, сприяє більшим втратам води за рахунок теч в водопровідній мережі, а отже й додатковим перевитратам електричної енергії, яка витрачається насосними агрегатами на компенсацію втрати тиску [1].

Зміни в часі водоспоживання, як i електроспоживання, $є$ випадковими процесами, тобто функції випадковим чином залежні від часу, а також від низки внутрішніх і зовнішніх факторів. Тобто, водоспоживання - непостійний процес, домінуючими причинно-наслідковими факторами якого є час доби та соціальні фактори. У свою чергу, електроспоживання визначається об'ємами води, яка проходить через структурні елементи системи водопостачання, a також певними технологічними факторами, вплив яких можна коректувати шляхом оптимізації режиму роботи.

Практика показує, що насоси значний період є недовантаженими. Пояснюється це тим, що проектувальники вибирають електродвигуни з запасом потужності, або тим, що витрата споживаної води змінюється, і двигун працює при максимальному навантаженні короткочасно. Регулювати витрату можна i при повній швидкості двигуна, змінюючи гідравлічний опір трубопроводів за допомогою клапанів або заслінок, однак, додаткове обладнання, необхідне в цьому випадку, часто виявляється ненадійним, важко регульованим i споживає багато енергії. Експлуатація такої системи без постійного прикривання засувки на виході неможлива, оскільки можуть виникати розриви трубопроводів.

Більш раціональним способом регулювання є зниження частоти обертання приводного двигуна насоса при збереженні незмінної характеристики навантаження.

Аналіз останніх досліджень та публікацій. При правильному виборі насосного агрегату його механічна характеристика i потужність електродвигуна 
"Енергетика і автоматика", №2, 2021 р.

розраховані на забезпечення необхідного тиску в системі при максимальному споживанні води, яке, як відомо, припадає на ранкові і вечірні години. В інший час доби із-за зниження споживання води тиск в системі зростає і потрібно прикривати засувку, а це вимагає постійного чергування біля неї і супроводжується втратами електроенергії.

Таким чином, технологія дросельного регулювання тиску (за допомогою засувок):

1) неекономічна;

2) вимагає постійного контролю черговим персоналом;

3) допускає великі коливання тиску і збільшує ймовірність аварій на трубопроводах;

4) викликає підвищений знос устаткування (насосів, засувок, електродвигунів).

Керування продуктивністю великої кількості насосів здійснюється введенням у мережу трубопроводів машин додаткового гідравлічного опору. Проте, цей метод призводить до невиправданих втрат енергії і передчасного зносу устаткування [2].

Насосні агрегати обладнують нерегульованим електроприводом. Регулювання подачі здійснюється при цьому практично єдиним способом - дроселювання на стороні нагнітання [3].

Застосування регульованих електроприводів у системах водопостачання, перш за все, дозволяє істотно знизити споживання електроенергії електроприводами насосів, оскільки надмірний напір в цьому випадку не створюється. Тиск підтримується постійним, за рахунок регулювання частоти обертання електродвигуна насоса, вимірюється датчиком і подається в електропривод у вигляді електричного сигналу зворотного зв'язку. Після порівняння заданого i реального тисків вбудованим в перетворювач частоти регулятором виробляється необхідна частота напруги, що надходить на електродвигун. Асинхронний електродвигун насосного агрегату обертається відповідно з частотою поданої на нього напруги. Таким чином, тиск в системі цілодобово автоматично підтримується постійним, незалежно від споживання води. 
"Енергетика і автоматика", №2, 2021 р.

Насосні станції, в яких використовуються відцентрові насоси для перекачування води та інших рідин, споживають до 25 \% всієї електроенергії, що виробляється. Робота цих систем відрізняється нерівномірним споживанням води протягом доби, залежно від погодних умов, пори року.

Насоси, як правило, працюють у системі з протитиском, причому статичний тиск в системі складає в більшості випадків не менше 20 \% повного тиску. Виключенням $\epsilon$ циркуляційні насоси, які можуть працювати на мережу трубопроводів, де практично не має статичного тиску.

Мета дослідження - обгрунтування енергоефективної водонасосної установки на основі частотно-регульованого електропривода.

Матеріали та методи дослідження. Регулювання подачі води насосом застосовують в таких випадках:

- при необхідності регулювання кількості рідини, що подається насосом, у відповідності до вимог технологічного процесу або у зв'язку з випадковою зміною потреби в рідині (подача води насосом повинна змінюватися відповідно режиму водоспоживання);

- якщо не потрібне під час роботи регулювання подачі рідини насосом, забезпечення необхідної подачі пов'язано 3 первинним підрегулюванням насоса. Наприклад, для подачі рідини на певну висоту Н при постійних витраті Q i опорі гідромережі 3 каталогу вибирається насос 3 найближчими параметрами 3 номінальним тиском і витратою води. Тому для роботи із заданими параметрами тиск і витрата води насоса повинні бути понижені до необхідних значень. Якщо насос працює при незмінній швидкості, то найпростішим способом регулювання його подачі є той, що дроселює, тобто неповне відкриття засувки на напірному трубопроводі насоса.

Продемонструємо добре відому енергетичну і технологічну неефективність дросельного регулювання подачі води насосом. Потужність, споживана насосом, визначається за формулою: 


$$
P=\frac{Q H g \rho}{\eta},
$$

де $\mathrm{P}$ - потужність, кВт; Q - подача, м $^{3} / \mathrm{c} ; \mathrm{H}$ - тиск, м; g - прискорення вільного падіння, м/ $\mathrm{c}^{2} ; \rho-$ густина рідкого середовища, кг/ ${ }^{3} ; \eta-$ ККД насоса.

Можливості енергозберігаючого управління при регулюванні швидкості електропривода порівняно з дросельним регулюванням проілюстровані на рис. 1 .

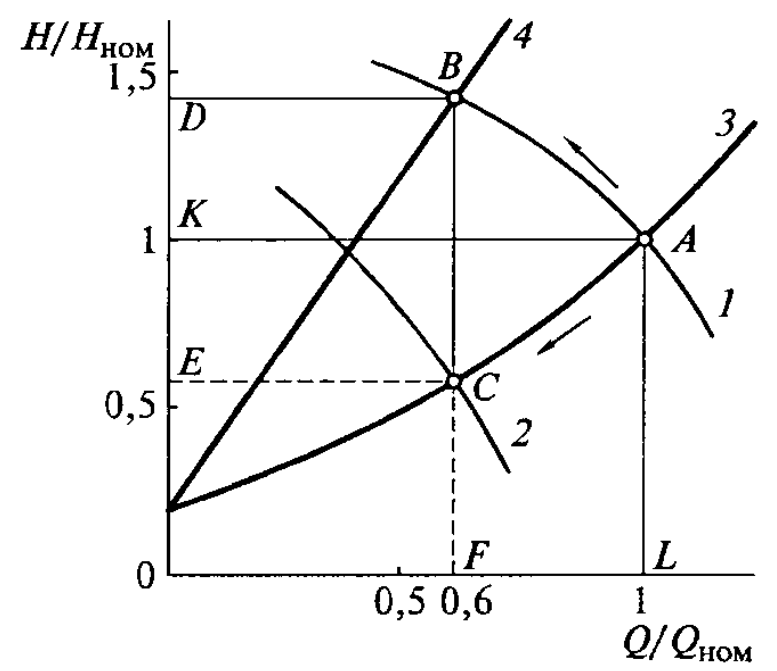

\section{Рис.1. Характеристики продуктивності відцентрового насоса при дросельному і частотному регулюванні}

За рахунок зменшення швидкості насос працює при зниженні витрати в точці 3 на кривій 2 при незмінній характеристиці магістралі (крива 3). Потужність, споживана електроприводом в цьому випадку, пропорційна площі прямокутника OECF, що наочно ілюструє можливості істотного зниження енергоспоживання при впровадженні регульованих електроприводів насосів. Разом з цим зменшується при зниженні витрати води і тиск в системі, що приводить до зменшення втрат (витоків) води.

Як вказувалося вище, сталий режим роботи насосної установки при постійній швидкості приводного електродвигуна визначається точкою перетину характеристики насоса, відповідній цій частоті, і характеристики магістралі, 
"Енергетика і автоматика", №2, 2021 р.

підключеної до насоса. Характеристикою насоса є залежність тиску Н від витрати Q, яку з достатнім ступенем точності можна представити у вигляді:

$$
H=H_{\text {он }}\left(\frac{\omega}{\omega_{\text {но. }}}\right)^{2}-C Q^{2},
$$

де $H_{0 H}$ - тиск насоса при $Q=0$ і $\omega=\omega_{\text {ном }} ; \omega_{\text {ном }}$ - номінальна швидкість електродвигуна; C - конструктивний коефіцієнт насоса, $C=\left(H_{0 H}-H_{\text {ном }}\right) / 2 Q_{\text {ном }} ; Q_{\text {ном }}$ i

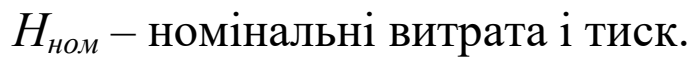

Характеристика магістралі визначається так:

$$
H=H_{c}+R Q^{2},
$$

де $H_{c}$ - статичний тиск (протитиск) при $\mathrm{Q}=0$ (закритій засувці); $R$ - коефіцієнт опору магістралі, $R=\left(H_{\text {ном }}-H_{c}\right) / 2 Q_{\text {ном. }}$.

Характеристики способів регулювання відцентрового насоса i магістралі наведені на рис. 2.

Потужність, споживана насосною установкою $з$ мережі:

$$
P_{1}=P_{\text {мex }} / \eta_{1},
$$

де $P_{\text {мех }}-$ потужність на валу двигуна насоса, $P_{\text {мех }}=M_{c} \omega ; M_{\mathrm{c}}-$ статичний момент навантаження на валу двигуна; $\eta_{1}-$ КПД двигуна.

Регулювання подачі дросельною заслінкою основано на зміні опору магістралі. У цьому випадку при $\omega=\omega_{\text {ном }}=$ const робоча точка механізму переміщається за $Q-H$ характеристикою, відповідної номінальної швидкості двигуна, у бік зниження подачі до точки перетину з новою характеристикою магістралі (точки, 3 на рис. 2).

При електричному способі регулювання подачі робоча точка переміщається за незмінною характеристикою магістралі (точки, 4, 5, 6, 7 на рис. 2). У цьому випадку зі зменшенням подачі зменшується і необхідний тиск, що приводить до зниження статичної потужності, необхідної для роботи насоса із заданою витратою води, порівняно з дросельним регулюванням.

При регулюванні дросельною заслінкою, коли $\omega=\omega_{\text {ном }}=$ const, ККД двигуна постійний і визначається за формулою $\eta_{1}=\left(1-\mathrm{s}_{\text {ном }}\right) /\left(\mathrm{as}_{\text {ном }}+1\right)$. 


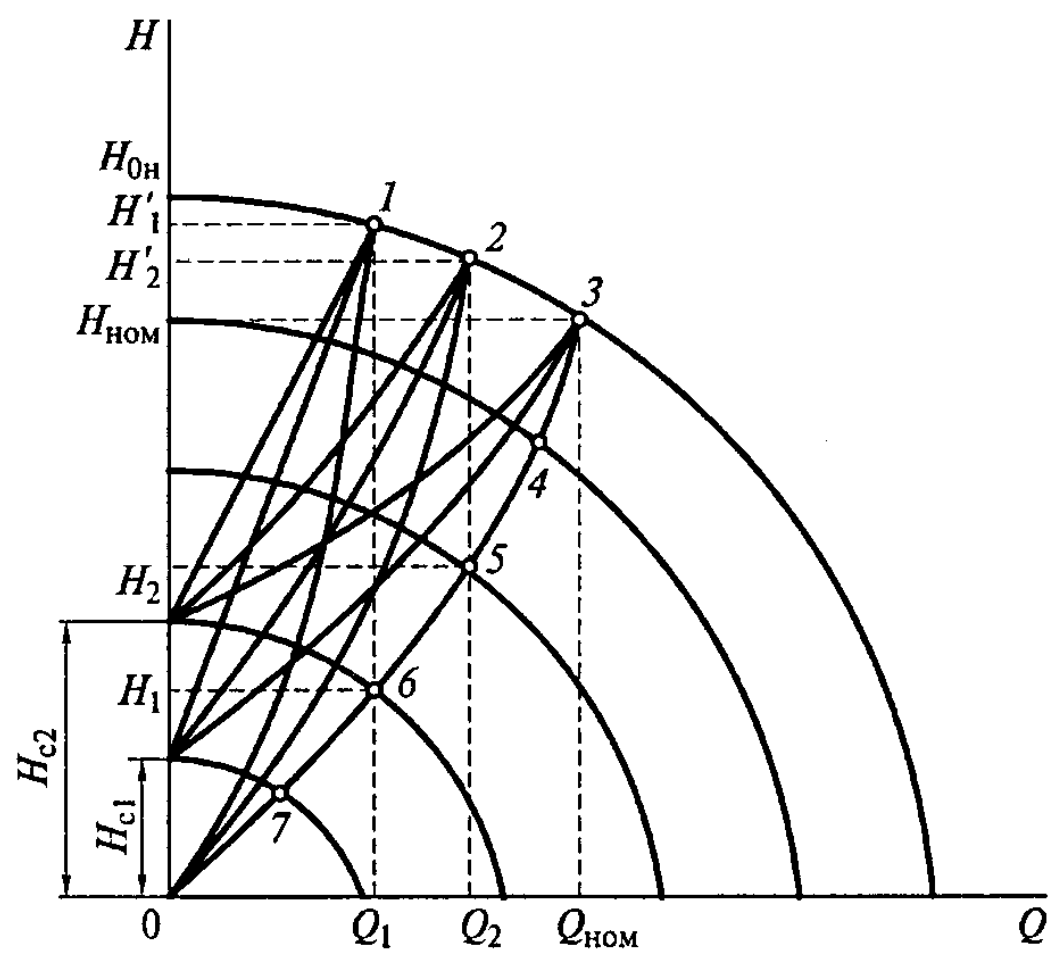

\section{Рис. 2. Характеристики способів регулювання відцентрового насоса:}

1, 2, 3 - робочі точки при дросельному регулюванні подачі; 4, 5, 6, 7 - робочі точки при регулюванні подачі за рахунок зміни частоти обертання двигуна

Щоб отримати розрахункові вирази у функції від витрати і ковзання двигуна, запишемо:

$$
\eta_{1}=\frac{1}{1+\frac{\omega_{\text {ном }}}{\omega} \frac{S_{\text {ном }}}{1-S_{\text {ном }}}(1+a)},
$$

де $s_{\text {ном }}$ - номінальне ковзання двигуна; а - відношення активних опорів фази статора $R_{l}$ i ротора $R^{\prime}{ }_{2}, a=R_{l} / \mathrm{R}^{\prime}{ }_{2}$.

У формулі (2) замінимо $\left(\omega / \omega_{\text {ном. }}\right)^{2}$ на $(1-s) /\left(1-s_{\text {ном }}\right)^{2}$ і спільно з виразом (3) щодо s, отримаємо:

$$
S=1-\left(1-S_{\text {ном }}\right) \sqrt{h_{c}+Q_{*}^{2}\left(1-h_{c}\right)}=1-\left(1-S_{\text {ном }}\right) A
$$

де $h_{c}=H_{c} / H_{0 н} ; Q^{*}=Q_{\text {ном }} ; A=\sqrt{h_{c}+Q_{*}^{2}\left(1-h_{c}\right)}$.

Залежність вираженого у відносних одиницях моменту на валу турбомеханізму при роботі його на мережу постійними параметрами має вигляд: 


$$
\mu=\mu_{0 c}\left(\frac{\omega}{\omega_{\text {ном }}}\right)^{2}+\left(1-\mu_{0 c}\right) \frac{\omega}{\omega_{\text {ном }}} \sqrt{\frac{\left(\omega / \omega_{\text {ном }}\right)^{2}-h_{c}}{1-h_{c}}}
$$

де $\mu$ - відносний момент на валу турбомеханізму, $\mu=M / M_{c \max }\left(M_{c \max }-\right.$ максимальний статичний момент на валу механізму, який має місце при $\left.\quad \omega=\omega_{\text {ном }}\right) ; \mu_{0 c}-$ статичний момент на валу $\left(M_{0 c}\right)$ при $Q^{*=0}$ (закритій засувці), виражений у відносних одиницях, $\mu_{0 c}=M_{0 c} / M_{c m a x}$.

Вирази (6) і (7) дозволяють поєднати момент, ККД, швидкість і потужність, споживану з мережі, у функції від витрати води при заданому протитиску. Для універсального використовування розрахункових формул доцільно визначати потужність $P_{l}$ у відносних одиницях $\left(P_{1^{*}}=P_{l} / P_{6}\right)$, прийнявши як базове значення потужності $P_{\sigma}$ максимальну статичну потужність на валу двигуна $P_{\text {cmax }}$ при $\omega=\omega_{\text {ном }}$, тобто $P_{\sigma}=P_{\text {стах }}=M_{\text {стах }} \omega_{\text {ном. }}$

Якщо вважати, що $M_{\text {сmax }}=M_{\text {ном }}\left(M_{\text {ном }}-\right.$ номінальний момент двигуна, $\mathrm{M}_{\text {ном }}=$ $\left.P_{\text {ном }} / \omega_{\text {ном }}\right)$, то базова потужність $P_{\sigma}=P_{\text {ном }}$.

Вирази для розрахунку $P_{1 *}$ при різних способах регулювання подачі насоса приймають такий вигляд:

при дросельному регулюванні:

$$
P_{1^{*}}=\frac{\left[\mu_{0 c}+\left(1-\mu_{0 c}\right) Q_{*}\right]\left(1+a S_{\text {ном. }}\right)}{1-S_{\text {ном }}},
$$

при частотному регулюванні:

$$
P_{1^{*}}=\left[\mu_{0 c} A^{3}+\left(1-\mu_{0 c}\right) A^{2} Q_{*}\right]\left[1+\frac{S_{\text {ном }}(1+a)}{\left(1-S_{\text {ном }}\right) A}\right] .
$$

Вирази (8) і (9) дозволяють розрахувати споживану насосом потужність при дросельному і частотному регулюванні залежно від витрати рідини $Q^{*}$ і провести порівняльну оцінку для даних способів регулювання. Відповідно до (8) і (9), при дросельному регулюванні для заданого значення $Q^{*}$ споживана потужність $P_{I} *$

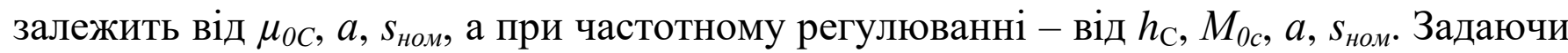
ці параметри для конкретних умов роботи насосного агрегату і вибраного двигуна або відрізка серії двигунів, можна розрахувати значення $P_{1}^{*}=f\left(Q^{*}\right)$. 
"Енергетика і автоматика", №2, 2021 р.

Використовуючи формули (8) і (9), можна отримати відому залежність, що ілюструє виграти в споживанні активної енергії при частотному регулювано 3 дросельним регулюванням. На рис. 3 наведена залежність $P_{1}^{*}=f\left(Q^{*}\right)$ при дросельному і частотному регулюванні для $h_{C}=0$. Задаючи витрату $\left(Q_{i} *\right)$, можна розрахувати споживану потужність при дросельному $\left(P_{1 i^{*} l}\right)$ i частотному регулюванні $\left(P_{1 i^{*} 2}\right)$ і визначити виграш в споживаній потужності $\Delta P_{1^{*} I}=P_{1 i^{*} I^{-}} P_{l^{*} *_{2}}$, що дозволяє розрахувати зниження річних витрат за вартістю електроенергії.

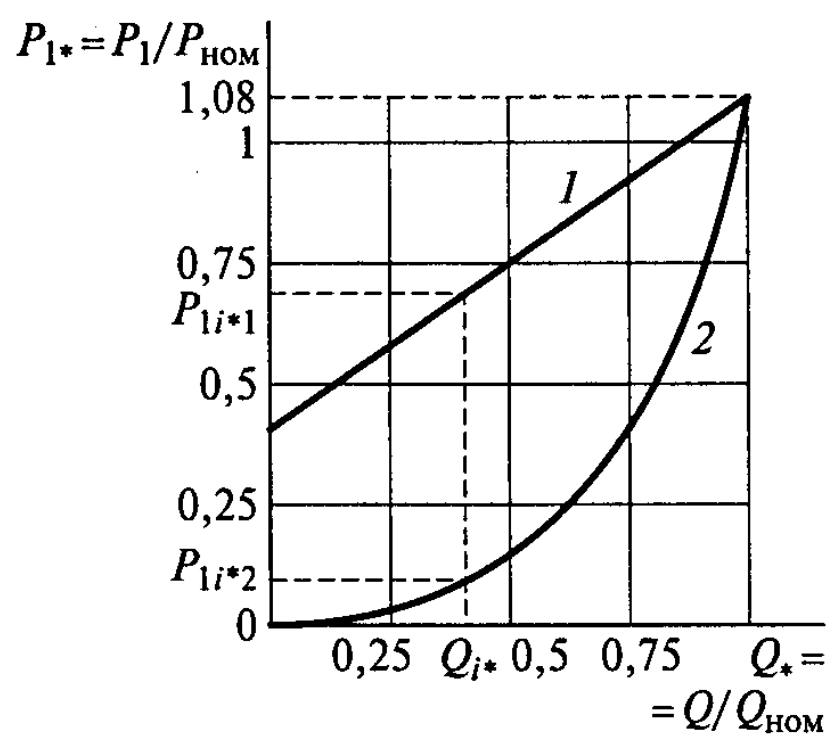

Рис. 3. Залежність $P_{1^{*}}=f\left(Q^{*}\right)$ при дросельному (крива 1$)$ і частотному (крива 2) регулюванні

Зі збільшенням статичного тиску $h_{C}$ знижується економія електроенергії при впровадженні частотно-регульованого асинхронного електропривода, проте при будь-яких значеннях $h_{C}$ система технологічної автоматизації забезпечує підтримку постійного тиску в системі незалежно від витрати, що дозволяє уникати непотрібних надлишків тиску, властивих дросельному регулюванню. Це дуже важливо, оскільки в комунальній сфері для існуючих систем, які не знаходяться в аварійному стані, кожна зайва атмосфера, а цей тиск 10 м водяного стовпа, викликає додатково 2,7 \% втрат води за рахунок витоків [4]. 
"Енергетика і автоматика", №2, 2021 р.

Завдяки квадратичній характеристиці $\left(U / f^{2}\right)$ і можливості їі динамічного вибору, перетворювач дозволяє управляти насосами 3 найбільшою ефективністю, наближаючись до їх природної характеристики і тим самим скорочуючи втрати енергії.

Для визначення основних співвідношень асинхронного електродвигуна при різних законах частотного регулювання використовуємо $\mathrm{T}$ - подібну схему заміщення електродвигуна зі змінними параметрами при частотному регулюванні.

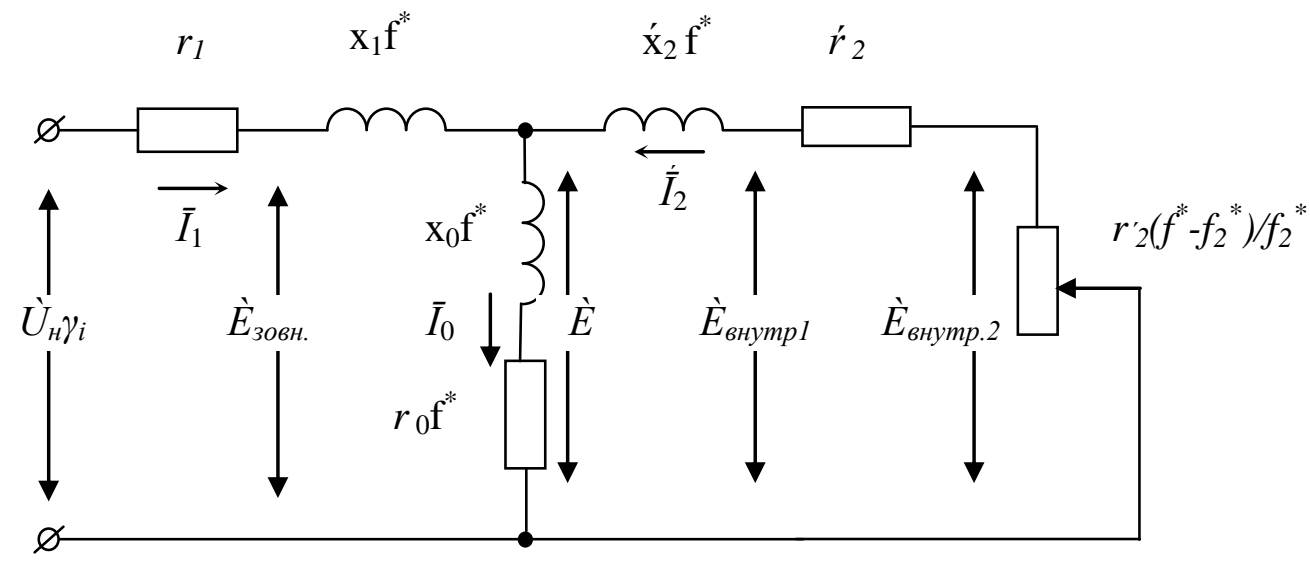

Рис. 4. Схема заміщення асинхронного короткозамкненого електродвигуна зі змінними параметрами при частотному керуванні

У наведеній схемі заміщення (рис. 4) всі опори за виключенням активних опорів обмоток статора $R_{1}$ і ротора $R_{2}^{\prime}$ змінюються пропорційно коефіцієнту $f^{*}=$ $f_{1} / f_{1 \mathrm{H}}$, де $f_{1}-$ поточне значення частоти; $f_{1 \mathrm{H}}-$ номінальне значення частоти перетворювача.

Прикладена напруга змінюється пропорційно коефіцієнту $\gamma=U_{l} / U_{1 н}$, де $U_{1}-$ поточне значення напруги, $\mathrm{B} ; U_{1 н}-$ номінальне значення напруги перетворювача, $\mathrm{B}$.

Навантаження на валу електродвигуна еквівалентне зведеному опору, який залежить від коефіцієнта $f^{*}$ i коефіцієнта абсолютного ковзання $f_{2}{ }^{*}=f_{2} / f_{1 \mathrm{H} .}=f^{*} \cdot s$,де $f_{2}-$ частота ротора, Гц; $s-$ ковзання двигуна.

При використанні першого закону другого рівня, при якому забезпечується постійне значення потокозчеплення $\psi_{1}$, тобто підтримування постійним значення

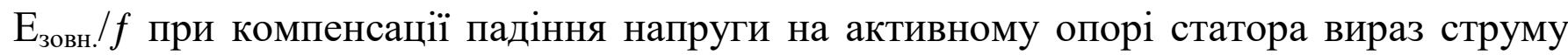
статора при такому регулюванні буде мати вигляд [5]: 


$$
\dot{I}_{1}=\dot{U}_{H} \gamma \frac{r_{0}+\frac{r_{2}^{\prime}}{f_{2}^{*}}+j\left(x_{0}+x_{2}^{\prime}\right)}{j x_{1} f^{*}\left(r_{0}+j x_{0}+\frac{r_{2}^{\prime}}{f_{2}^{*}}+j x_{2}^{\prime}\right)+\left(\frac{r_{2}^{\prime}}{f_{2}^{*}}+j x_{2}^{\prime}\right)\left(f^{*} r_{0}+j f^{*} x_{0}\right)} .
$$

Напруга на вході схеми повинна бути більша ЕРС на величину опору напруги на активному опорі статора, яка визначається виразом:

$$
\dot{U}_{B x}=\dot{U}_{H} \gamma+\dot{I}_{1} r_{1}=\dot{U}_{H} \gamma\left[1+r_{1} \frac{r_{0}+\frac{r_{2}^{\prime}}{f_{2}^{*}}+j\left(x_{0}+x_{2}^{\prime}\right)}{j x_{1} f^{*}\left(r_{0}+j x_{0}+\frac{r_{2}^{\prime}}{f_{2}^{*}}+j x_{2}^{\prime}\right)+\left(\frac{r_{2}^{\prime}}{f_{2}^{*}}+j x_{2}^{\prime}\right)\left(f^{*} r_{0}+j f^{*} x_{0}\right)}\right],
$$

тоді коефіцієнт збільшення напруги $\gamma_{1}$ має вигляд:

$$
\dot{\gamma}_{1}=\frac{\dot{U}_{B x}}{\dot{U}_{H}}=\gamma\left[1+r_{1} \frac{r_{0}+\frac{r_{2}^{\prime}}{f_{2}^{*}}+j\left(x_{0}+x_{2}^{\prime}\right)}{j x_{1} f^{*}\left(r_{0}+j x_{0}+\frac{r_{2}^{\prime}}{f_{2}^{*}}+j x_{2}^{\prime}\right)+\left(\frac{r_{2}^{\prime}}{f_{2}^{*}}+j x_{2}^{\prime}\right)\left(f^{*} r_{0}+j f^{*} x_{0}\right)}\right] .
$$

Абсолютне значення коефіцієнта збільшення напруги з (11) обчислюється за виразом:

$$
\gamma_{1}=\sqrt{\frac{\left(\frac{r_{0} r_{2}}{s}+r_{1}\left(r_{0}+\frac{r_{2}}{f_{2}^{*}}\right)-x_{1} f^{*}\left(x_{0}+x_{2}\right)-x_{2} x_{0} f^{*}\right)^{2}+}{\left(r_{0} r_{2} / s-x_{1} f^{*}\left(x_{0}+x_{2}\right)-x_{2} x_{0} f^{*}\right)^{2}+}} \rightarrow
$$

Оскільки $f_{2}{ }^{*}=f^{*} s$, то вимірюючи швидкість електродвигуна при заданій частоті напруги живлення $f^{*}$ визначають $f_{2}^{*}$ і коефіцієнт збільшення напруги, яка прикладається до затискачів електродвигуна.

Необхідно також відзначити вже згадувану раніше функцію динамічного вибору характеристики U/f. При зниженні навантаження на валу двигуна i, відповідно, зменшенні струму статора перетворювач знижує напругу на статорі двигуна, зберігаючи частоту незмінною. Завдяки зниженню напруги зменшуються втрати енергії в статорі двигуна, а значить, і загальні втрати енергії в приводній системі стають нижчими. При зростанні навантаження на валу двигуна процес протікає в зворотній послідовності i ПЧ повертається на номінальну характеристику. 
"Енергетика і автоматика", №2, 2021 р.

Результати досліджень та їх обговорення. На величину втрат при дросельному регулюванні впливає не тільки регулюючий елемент: найчастіше на етапі проектування вибирається насосний агрегат із певним запасом тиску, а при заміні насосних агрегатів нове устаткування може мати дещо завищені характеристики. Крім того, діапазон зміни вхідного тиску (перед всмоктувальним патрубком насосного агрегату) впливає на величину тиску за насосним агрегатом. Всі ці обставини призводять до того, що втрати енергії в ході технологічного процесу стають досить великими, досягаючи 45 і більше відсотків від номінальної потужності агрегату. Для вирішення завдання мінімізації втрат, пов'язаних 3 регулюванням тиску в мережі, необхідно виключити додаткові гідравлічні опори на ділянці від насосного агрегату до трубопроводу, тобто необхідно повністю відкрити всю запірно-регулюючу арматуру. Це можна зробити, якщо процес регулювання тиску передати насосному агрегату.

Теорія роботи нагнітачів (насосів і вентиляторів) доводить, що зміна частоти обертання приводу нагнітача змінює його напірні характеристики, крім того, тиск, створюваний нагнітачем, пропорційний квадрату частоти обертання агрегату. Якщо організувати роботу привода насосного агрегату таким чином, щоб він при зміні параметрів технологічного процесу змінював частоту обертання, то можна без суттєвих втрат енергї стабілізувати тиск в мережі споживачів. При такому способі регулювання виключаються втрати напору (немає дросельних елементів), а як наслідок, і втрати гідравлічної енергії.

Спосіб регулювання тиску в мережі шляхом зміни частоти обертання привода насосного агрегату знижує енергоспоживання ще й 3 іншої причини. Власне насос як пристрій перетворення енергії має свій коефіцієнт корисної дії - відношення механічної енергії, прикладеної до валу, до гідравлічної енергії, яка отримується в напірному трубопроводі насосного агрегату. У відповідності 3 теорією подібності максимум коефіцієнта корисної дії із зменшенням частоти обертання трохи знижується і зміщується вліво. Аналіз необхідного зниження частоти насосного агрегату при зміні витрат в мережі показує, що із зменшенням витрати необхідно знизити частоту обертання. Якщо розглянути роботу агрегату для витрати меншої за 
"Енергетика і автоматика", №2, 2021 р.

номінальну, то для цих режимів раціональніше працювати на зниженій частоті обертання. У цьому випадку ККД насоса вище, ніж при роботі на номінальній частоті обертання. Таким чином, зниження частоти обертання у відповідності із технологічним навантаженням дозволяє не тільки економити споживання енергії на виключення гідравлічних втрат, але й отримати економічний ефект за рахунок підвищення коефіцієнта корисної дії самого насоса - перетворювача механічної енергії в гідравлічну.

Висновки i перспективи. Проблема енергозбереження при роботі електронасосів водопостачання не втрачає актуальності.

У ході наукового дослідження двох способів регулювання технологічних параметрів водонасосної електроустановки з'ясовано:

- за традиційної технології дроселювання зміна витрат і тиску води не призводить до зміни енергоспоживання (нерегульований електропривод працює на номінальних обертах);

- за частотного регулювання енергоспоживання відбувається у відповідності до технологічних параметрів водопровідної мережі. Зокрема, автоматичне підтримання тиску при зміні витрати води відбувається за рахунок застосування частотнорегульованих асинхронних електроприводів.

Перспективи подальших досліджень вбачаємо у наукових дослідженнях 3 моделювання режимів роботи електронасосної установки з метою підтвердження достовірності розглянутих способів регулювання.

Таким чином, приведені міркування об'єктивно підтверджують необхідність переходу від систем дросельного регулювання насосних агрегатів до систем автоматичного керування шляхом зміни частоти струму приводного електродвигуна.

\section{Список використаних джерел}

1. Давиденко Л. В. Багатокритерійна оптимізація режиму електроспоживання підприємств комунального водопостачання. Підвищення енергоефективності енергоспоживання в електротехнічних пристроях і системах. Матеріали II-Ї міжнар. наук.-технічн. конф. Луцьк: РВВ ЛНТУ, 2008. 212 с.

2.Електропривід сільськогосподарських машин, агрегатів та потокових ліній: за ред. Жулая Є. Л. К.: Виша освіта, 2001. 288 с. 
"Енергетика і автоматика", №2, 2021 р.

3. Лезнов Б. Энергосбережение и регулируемый электропривод в насосных установках водоподачи и водоотведения. Экологические системы. 2004. № 11. С 4552.

4. Попович М. Г., Печеник М. В., Кіселичник О. І., Соколовський О. Ф. Енергозберігаючі інтерактивні електромеханічні системи автоматичного керування насосними установками. Електромашинобудування та електрообладнання. Тематичний випуск: проблеми автоматизованого електропривода. Випуск 66 . Київ: «Техніка», 2006. С. 311-314.

5. Петрушин В. С. Регулировочные характеристики инхронного электродвигателя в частотном электроприводе при законах управления, обеспечивающих постоянства потокосцеплений. Електротехніка і електромеханіка. 2002. №2. C. 53 - 55.

\section{References}

1. Davydenko, L. V. (2008). Bahatokryteriina optymizatsiia rezhymu elektrospozhyvannia pidpryiemstv komunalnoho vodopostachannia. Pidvyshchennia enerhoefektyvnosti enerhospozhyvannia v elektrotekhnichnykh [Multicriteria optimization of the mode of electricity consumption of municipal water supply enterprises]. Pidvyshchennia enerhoefektyvnosti enerhospozhyvannia $\mathrm{v}$ elektrotekhnichnykh prystroiakh i systemakh. Materialy II-I mizhnar. nauk.-tekhnichn. konf. Lutsk: RVV LNTU, 212.

2. Zhulai, Ye. L. (2001). Elektropryvid silskohospodarskykh mashyn, ahrehativ ta potokovykh linii [Electric drive of agricultural machines, units and production lines]. Kyiv: Vysha osvita, 288.

3. Leznov, B. (2004). Energosberezheniye i reguliruyemyy elektroprivod v nasosnykh ustanovkakh vodopodachi i vodootvedeniya [Energy saving and adjustable electric drive in pumping units for water supply and drainage]. Ekologicheskiye sistemy, 11, 45-52.

4. Popovych, M. H., Pechenyk, M. V., Kiselychnyk, O. I., Sokolovskyi, O. F. (2006). Enerhozberihaiuchi interaktyvni elektromekhanichni systemy avtomatychnoho keruvannia nasosnymy ustanovkamy [Energy-saving interactive electromechanical systems of automatic control of pumping units]. Elektromashynobuduvannia ta elektroobladnannia. Tematychnyi vypusk: problemy avtomatyzovanoho elektropryvoda, 66, 311-314.

5. Petrushinб V. S. (2002). Regulirovochn·yye kharakteristiki inkhronnogo elektrodvigatelya $\mathrm{v}$ chastotnom elektroprivode pri zakonakh upravleniya, obespechivayushchikh postoyanstva potokostsepleniy [Adjustment characteristics of an induction motor in a frequency drive under control laws that ensure constant flux linkages]. Yelektrotekhnika i yelektromekhanika, 2, $53-55$.

\section{ЭНЕРГОЭФФЕКТИВНАЯ НАСОСНАЯ УСТАНОВКА НА ОСНОВЕ ЧАСТОТНО-РЕГУЛИРУЕМЫХ ЭЛЕКТРОПРИВОДОВ \\ П. Б. Клендий, Л. С. Колодийчук, О. П. Дударь}

Аннотация. Электроводонасосные установки характеризуются не оптимальными режимами работь и на сегоднямний день являются 
"Енергетика і автоматика", №2, 2021 р.

энергозатратными технологиями. Водопотребление определяетмя неравномерностью и формируется под влиянием многих, часто неуправляемых факторов. Несоответствие запланированного режима водоснабжения реальному водопотреблению приводит к возникновению избыточных напоров, что приводит не только к прямым перерасходам электроэнергии на насосных станциях, но $u$ повынает вероятность аварий в сети, способствует большим потерям воды за счет течей в водопроводной сети, а, следовательно, и дополнительный перерасход электроэнергии, потребляемой насосными агрегатами на компенсацию потери давления.

При правильном выборе электронасосного агрегата его механическая характеристика и мощуность электродвигателя рассчитаны на обеспечение необходимого давления в системе при максимальном потреблении воды (утренние и вечерние часы). В другое время суток из-за снижения потребления воды давление в системе растет и нужно прикрывать дроссельную задвижку, а это требует постоянного дежурства у нее и сопровождается потерями электроэнергии.

В электронасосах, которые оборудуют нерегулируемым электроприводом, регулировка подачи осуществляется практически единственным традиционным способом - дросселированием на стороне нагнетания. В работе раскрыта необходимость перехода от систем дроссельного регулирования насосных агрегатов к системам автоматического управления путем автоматического поддержания необходимого технологического параметра, в частности, давления при изменяющемся расходе за счет применения частотно-регулируемых асинхронных электроприводов.

Ключевые слова: водонасосная установка, энергозатратные технологии, дросселирование, частотно-регулируемый электропривод

\title{
ENERGY EFFICIENT WATER PUMPING INSTALLATION ON THE BASIS OF FREQUENCY-REGULATED ELECTRIC DRIVE
} P. Klendiy, L. Kolodiychuk, O. Dudar

\begin{abstract}
Electric pumping units are not characterized by optimal operating modes and today are energy-intensive technologies. Water consumption is determined by unevenness and is formed under the influence of many, often uncontrollable factors. The inconsistency of the planned water supply regime with the actual water consumption leads to excessive pressures, which causes not only direct overconsumption of electricity at pumping stations, but also increases the likelihood of accidents in the network, contributes to greater water losses due to leaks in the water supply network. additional overconsumption of electricity consumed by pumping units to compensate for pressure loss.

With the right choice of electric pump unit, its mechanical characteristics and power of the motor are designed to provide the required pressure in the system at maximum water consumption (morning and evening). At other times of the day, due to the decrease in water consumption, the pressure in the system increases and it is necessary to cover the throttle valve, and this requires constant rotation near it and is accompanied by electricity losses.
\end{abstract}


"Енергетика і автоматика", №2, 2021 р.

In electric pumps, which are equipped with an unregulated electric drive, the flow control is carried out in almost the only traditional way - throttle on the discharge side. The paper reveals the need for transition from throttle control systems of pump units to automatic control systems by automatically maintaining the required technological parameter, in particular, the pressure at the flow rate of changing water due to the use of frequency-regulated asynchronous electric drives.

Keywords: water pumping unit, energy consuming technologies, throttling, frequency-regulated electric drive 